\title{
AUTHOR CORRECTION
}

\section{Correction for Zhang et al., Toxin-Mediated Paracellular Transport of Antitoxin Antibodies Facilitates Protection against Clostridium difficile Infection}

Z. Zhang, ${ }^{a}$ X. Chen, ${ }^{\text {b L. D. Hernandez, }}{ }^{\text {a P. Lipari, }}{ }^{\text {a A. Flattery, }}{ }^{\text {a }}$ S.-C. Chen, ${ }^{\text {a }}$ S. Kramer, ${ }^{\text {a }}$ J. D. Polishook, ${ }^{\text {a }}$ F. Racine, ${ }^{\text {a }}$ H. Cape, ${ }^{\text {a }}$ C. P. Kelly, ${ }^{b}$ A. G. Therien ${ }^{a}$

Merck Research Laboratories, Merck \& Co., Inc., Kenilworth, New Jersey, USAa; Division of Gastroenterology, Beth Israel Deaconess Medical Center, Harvard Medical School, Boston, Massachusetts, USA

Volume 83, no. 1, p. 405-416, 2015. Page 408: Figure 1 should appear as shown below.

A

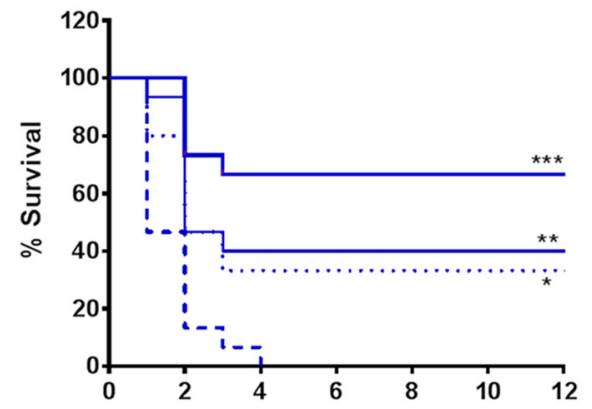

Time following $C$. difficile challenge (days)

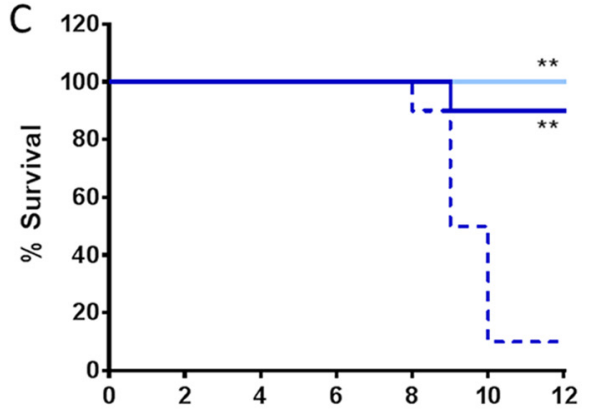

Time following $C$. difficile challenge (days)
B

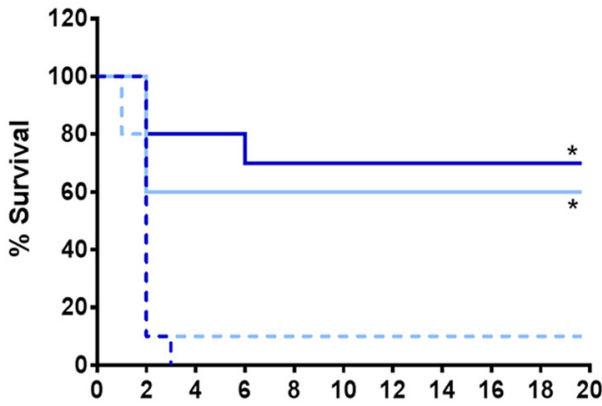

Time following $C$. difficile challenge (days)

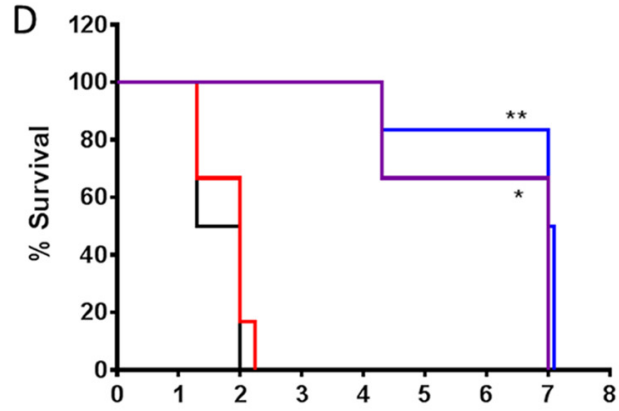

Time following $C$. difficile challenge (days)

FIG 1

Citation Zhang Z, Chen X, Hernandez LD, Lipari P, Flattery A, Chen S-C, Kramer S, 